\title{
Screening of commercial enzymes for the enantioselective hydrolysis of $R, S$-naproxen ester
}

\author{
Lucia Steenkamp ${ }^{\mathrm{a}, *}$, Dean Brady ${ }^{\mathrm{a}}$ \\ a Process Biotechnology Programme, Bio/Chemtek, CSIR, Private Bag X2, Modderfontein 1645, South Africa
}

Received 11 January 2002; accepted 8 December 2002

\begin{abstract}
This study focused on the identification of suitable lipase or esterase activity for enantiomeric resolution of $(R, S)$-naproxen. For an economically viable reaction the enantiomeric ratio $(E)$ should preferably be $>100$, while maximising the conversion will reduce the mass of material that requires racemisation and recycling. Hence the aim was to find an enzyme that yields $(S)$-naproxen with an enantiomeric excess of more than $98 \%$, a substrate conversion in excess of $40 \%$ of the racemate, and an $E$ of $>100$. $(R, S)$-Naproxen ethyl ester (NEE) $(50 \mathrm{mg})$ was used as substrate for enzyme hydrolysis reactions at $37^{\circ} \mathrm{C}$ for $4 \mathrm{~h}$. Biocatalyst screening was performed in buffered aqueous solvent on a $1 \mathrm{ml}$ scale. The reactions were stopped with $2 \mathrm{ml} \mathrm{MeCN}$, filtered through cotton wool and analysed by HPLC to determine the percentage $\mathrm{m} / \mathrm{m}$ and $R / S$ ratio.

Eight commercially available enzymes were selected for optimisation of enantioselectivity through statistically designed experiments where the reaction conditions were varied. ChiroCLEC-CR from Altus and ESL001-01 from Diversa provided acceptable enantiomeric excess, but only ChiroCLEC-CR met the specification set for the enantiomeric ratio $(E)$.
\end{abstract}

(C) 2002 Elsevier Science Inc. All rights reserved.

Keywords: Enantioselectivity; Hydrolysis; Naproxen; Enzymes; Lipase; Esterase

\section{Introduction}

Hydrolytic enzymes are the most commonly used biocatalysts in organic synthesis. Two of the most useful hydrolase enzymes are esterases and lipases, which catalyse the hydrolysis and formation of carboxylic ester bonds. In recent years hydrolytic enzymes have been widely applied to the kinetic resolution of racemic acids and alcohols. Both esterases and lipases have been used to catalyse synthetically useful reactions: ester hydrolysis, esterification (alcohol and acid), transesterification (alcohol and ester), intraesterification (ester and acid) and transfer of acyl groups from esters to other nucleophiles such as amines, thiols, and hydroperoxide [1]. These reactions often proceed stereoselectively in aqueous, aqueous-organic or organic solvents. In particular, the enzymatic enantioselective resolution of two-substituted acids by lipases has been the subject of intensive investigation due to their high value as products or intermediates in the synthesis of pharmaceuticals or herbicides [2].

Naproxen (2-(6-methoxy-2-naphthyl)-propionic acid) is widely used as a drug for human connective tissue diseases

\footnotetext{
* Corresponding author. Tel.: +27-11-605-2738; fax: +27-11-608-3020.

E-mail address: 1steenkamp@csir.co.za (L. Steenkamp).
}

[3]. The $(S)$-enantiomer is 28 -fold more active than the corresponding $(R)$-enantiomer, warranting elimination of the unwanted enantiomer from the formulation. Hence, this compound is a suitable commercial candidate for demonstration of enzymatic resolution to provide a single enantiomer compound.

However, for a resolution process to be valuable, it must have a high selectivity. Therefore, for a commercial process it is important to determine the enantiomeric ratio $(E)$ for the process. $E$ is the parameter that is characteristic of both the enantioselectivity of a particular enzyme and the degree of conversion. $E$ is calculated using the following equation:

$E=\frac{\ln [(1-c)(1-\text { ees })]}{\ln [(1-c)(1+\text { ees })]}=\frac{\ln [1-c(1+\text { eep })]}{\ln [1-c(1-\text { eep })]}$

Enantiomeric excess (ee) is determined by the following equations:

ees $=\frac{[\mathrm{A}]-[\mathrm{B}]}{[\mathrm{A}]+[\mathrm{B}]} \quad$ eep $=\frac{[\mathrm{P}]-[\mathrm{Q}]}{[\mathrm{P}]+[\mathrm{Q}]}$

and conversion

$c=\frac{\text { ees }}{\text { ees }+ \text { eep }}$ 
where $[\mathrm{A}]$ and $[\mathrm{B}]$ are relative concentrations of the starting material enantiomers $(\mathrm{s})$ and $[\mathrm{P}]$ and $[\mathrm{Q}]$ are concentrations of the products ( $\mathrm{p})$.

During this study a rapid small scale $(1 \mathrm{ml})$ reaction method was used to screen for biocatalysts for the identification of a suitable hydrolytic enzyme for the enantiomeric resolution of $(R, S)$-naproxen which would ideally have an ee of $98 \%$, an $E$ of $>100$ and substrate conversion in excess of $40 \%$ of the racemate [4].

\section{Materials and methods}

\subsection{Chemicals}

Esterase/lipase CloneZyme kit was obtained from Diversa (CA, USA), three lipase/esterase kits from Fluka Chemie (AG Buchs), Chirazyme kit (Boehringer Mannheim) and a Chiroscreen EH kit (Altus Biologics Inc. Cambridge, USA). A variety of enzymes were kindly donated by various suppliers such as NOVO Nordisk (Denmark), Amano (Japan), Sigma Chemical Co (St Louis, USA) Nagase (Japan), and Biocatalysts (UK). (S)-Naproxen was obtained from Sigma Chemical Co (St Louis, USA) and all other chemicals were of analytical or of reagent grade.

\subsection{Analytical methods}

All sample analyses were performed by HPLC. The percentage $\mathrm{m} / \mathrm{m}$ was determined using a $25 \mathrm{~cm}$ C18 ODS 2 column eluted isocratically using a mixture of $70 \%$ acetonitrile and $30 \%$ buffer (made up of water and $0.1 \%$ phosphoric acid). $R / S$ ratios were determined on an (S-S)-Whelk/0/ $25 \mathrm{~cm}$ column run isocratically with an eluent mixture of hexane:ethanol:acetic acid (95:5:0.5).

\subsection{Preparation of racemic naproxen}

In our laboratories the substrate, racemic naproxen ester, was synthesised by racemisation of $(S)$-naproxen, followed by esterification. The racemate was prepared as follows: Ethanol $(95 \%, 200 \mathrm{ml})$ was added to a $500 \mathrm{ml}$ round bottom three-necked flask equipped with a reflux condenser and two stoppers, containing $(S)$-naproxen $(10.21 \mathrm{~g}, 0.0443 \mathrm{~mol})$. Sodium hydroxide $(20.48 \mathrm{~g}, 0.512 \mathrm{~mol})$ was added to the flask and the resulting mixture was refluxed at $\sim 80^{\circ} \mathrm{C}$ over 5 days. After this period, the mixture was cooled to $\sim 0{ }^{\circ} \mathrm{C}$ in an ice bath and acidified to $\mathrm{pH} 2$ with dilute sulphuric acid $(\sim 170 \mathrm{ml}$ of a $2 \mathrm{M}$ stock solution). The acidic mixture was extracted with diethyl ether $(3 \times 250 \mathrm{ml})$. The combined ethereal layers were evaporated and the remaining brown solid residue was washed with water $(\sim 250 \mathrm{ml})$ and chloroform $(4 \times 250 \mathrm{ml})$. The combined organic layers were dried over anhydrous $\mathrm{MgSO}_{4}$, and the chloroform was removed under vacuum to yield a beige solid $(10.25 \mathrm{~g}, 0.0445 \mathrm{~mol})$ that was identified to be $(R, S)$-naproxen by HPLC.

\subsection{Esterification of naproxen}

$(R, S)$-Naproxen (5 g) was suspended in methanol $(\sim 80 \mathrm{ml})$. Chlorine gas was bubbled into the reaction by evolution from $\mathrm{NH}_{4} \mathrm{Cl}(8 \mathrm{~g})$ in $\mathrm{H}_{2} \mathrm{SO}_{4}(\sim 40 \mathrm{ml})$. The reaction was completed over $2 \mathrm{~h}$ at room temperature, by which time all the solids were dissolved. The reaction was confirmed by TLC using hexane:ethyl acetate (9:1) as mobile phase. Ether $(100 \mathrm{ml})$ and $10 \% \mathrm{NaHCO}_{3}(100 \mathrm{ml})$ were added, and the ether layer was extracted and washed once with $\mathrm{H}_{2} \mathrm{O}$ $(100 \mathrm{ml})$. The organic phase was dried over $\mathrm{MgSO}_{4}$, decanted, and evaporated to leave a solid of $4.8 \mathrm{~g}$. The reaction was conducted in methanol or ethanol to yield the methyl ester or the ethyl ester respectively, as determined by HPLC.

\subsection{Biocatalytic hydrolysis of $(R, S)$-naproxen ethyl ester}

Reactions were performed (except where stated otherwise) in $1 \mathrm{ml}$ PEG/acetate buffer $\mathrm{pH} 5$ (enzymes with lipase activity), or in MOPS buffer $\mathrm{pH} 7$ (enzymes with esterase activity). ( $R, S)$-Naproxen ethyl ester (NEE) $(50 \mathrm{mg}$ ) was used as substrate and the reaction incubated at $37^{\circ} \mathrm{C}$ for $4 \mathrm{~h}$. The reactions were stopped with $2 \mathrm{ml} \mathrm{MeCN}$, filtered through cotton wool, and analysed by HPLC to determine the percentage $\mathrm{m} / \mathrm{m}$ and $R / S$ ratio.

These reaction conditions were applied to a wide variety of commercial enzyme preparations: Lipolase 100T, Lipomax CXT, Lipase PS (Pseudomonas cepacia), and Lipase AY (Candida cylindracea) (Amano); Candida antarctica lipase (Sigma); Lillipase (Nagase); Palatase, NOVO 388, NOVO 398, NOVO 868 and NOVO 525 (NOVO Nordisk); Chirazyme Kit (Boehringer Mannheim); Lipase from Chromobact. viscosum and Candida cylindracea (Biocatalysts); Hog-liver esterase (Boehringer 104698); Altus Chiro-CLEC; and Fluka lipases and esterases (listed in Table 1). However, for the Chiroscreen and Clonezyme kits, the buffers and instructions supplied with the kits were followed.

\subsection{Reaction optimisation by statistically designed experiments}

Eight enzymes were found to have selectivity for production of $(S)$-naproxen (ee $>10 \% S$ ) from the hydrolysis of NEE: NOVO 388; NOVO 398; Boehringer hog-liver esterase; Aspergillus niger (Fluka 62294); Mucor miehei (Fluka 62298); Aspergillus oryzae (Fluka 62285); ESL00101 (Batch 6Z); and ChiroCLEC-CR. The optimisation of ChiroCLEC-CR was extensive and will be described elsewhere. Further evaluation of the other seven enzymes was performed as a statistically designed experiment using a $0.5 \times 2^{4}$ factorial design with duplicates and two midpoints.

The final volumes of the reactions were $1 \mathrm{ml}$. The reaction temperature was maintained at $37^{\circ} \mathrm{C}$ (except for ESL001-01 which was $70^{\circ} \mathrm{C}$ ) and the stirring speed at $750 \mathrm{rpm}$ for $4 \mathrm{~h}$. The variables were: $\mathrm{pH} 5$ and 9 (pH 7 midpoint); PEG: 20 and 50\% (35\% midpoint); racemic substrate (NEE): 2 and 
Table 1

Fluka kit lipases and esterases, and enzymes used for comparison

\begin{tabular}{lll}
\hline No. & Catalogue no. & Enzyme source \\
\hline 1 & 62294 & Aspergillus niger \\
2 & 62299 & Candida antarctica \\
3 & 62316 & Candida cylindracea \\
4 & 62298 & Mucor miehei \\
5 & 62309 & Pseudomonas cepacia \\
6 & 62312 & Pseudomonas fluorescens \\
7 & 62305 & Rhizopus arrhizus \\
8 & 62310 & Rhizopus niveus \\
9 & 62300 & From hog pancreas (PPL) \\
10 & 62285 & Aspergillus oryzae \\
11 & 62303 & Candida lipolytica \\
12 & 62304 & Mucor javanicus \\
13 & 62308 & Penicillium roqueforti \\
14 & 62321 & Pseudomonas fluorescens \\
15 & 62291 & Rhizomucor miehei \\
16 & 62306 & From wheatgerm \\
17 & 62333 & Chromobact. viscosum \\
18 & 62335 & Pseudomonas species \\
19 & 62336 & Ps species type B \\
20 & 01022 & Acetylcholine esterase from eel \\
21 & 46062 & Bacillus species \\
22 & 46051 & Bacillus stearothermophilus \\
23 & 46054 & Bacillus thermoglucosidasius \\
24 & 46056 & Candida lipolytica \\
25 & 46059 & Mucor miehei \\
26 & 46069 & From horse liver \\
27 & 46071 & Saccharomyces cerevisiae \\
28 & 46058 & From hog-liver \\
30 & &
\end{tabular}

10\% (6\% midpoint); DMSO: 0 and 20\% (10\% midpoint). The buffers used were $0.5 \mathrm{M}$ sodium acetate $(0.5 \mathrm{M}, \mathrm{pH} 5)$; Tris $(0.5 \mathrm{M}, \mathrm{pH} 7)$; and Tris $(0.5 \mathrm{M}, \mathrm{pH} 9)$.

The different substrate concentrations investigated were $20 \mathrm{mg}(2 \%), 60 \mathrm{mg}(6 \%)$ and $100 \mathrm{mg}(10 \%)$. Generally $1 \mathrm{mg} / \mathrm{ml}$ lyophilised enzyme was added as biocatalyst, while $50 \mu \mathrm{l} / \mathrm{ml}$ of NOVO 388 and 398 and $100 \mu \mathrm{l} / \mathrm{ml}$ of Boehringer hog-liver esterase liquid preparations were used.

\section{Results}

\subsection{Initial screening of the commercial enzymes}

Through screening experiments, eight enzymes were identified as having satisfactory activities for the hydrolysis of naproxen ethyl ester to naproxen (Table 2), the other enzymes had either low activity, poor enantioselectivity, or the opposite enantioselectivity to that desired. Of particular interest, Altus 9 (ChiroCLEC-CR) gave the required enantioselectivity (ee $>98 \%$ ), an activity of $0.33 \mathrm{~g} / \mathrm{g} / \mathrm{h}$ and an enantiomeric ratio $(E)$ of 397, while ESL001-01 from the CloneZyme library (Diversa) provided an activity of $11.3 \mathrm{~g} / \mathrm{g} / \mathrm{h}$, an $R / S$ ratio (ee) of $81 \%(S)$ and enantiomeric ratio $(E)$ of 16.3 .
Table 2

Enzymes enantioselective for $(S)$-naproxen ethyl ester

\begin{tabular}{lll}
\hline Enzyme & Activity & eep (\%) \\
\hline NOVO 388 & $8.94 \mathrm{mg} / \mathrm{ml} / \mathrm{h}$ & 39 \\
NOVO 398 & $2.7 \mathrm{mg} / \mathrm{ml} / \mathrm{h}$ & 67 \\
Hog-liver esterase & $0.61 \mathrm{mg} / \mathrm{mg} / \mathrm{h}$ & 10 \\
Aspergillus niger & $0.09 \mathrm{mg} / \mathrm{mg} / \mathrm{h}$ & 42 \\
Mucor miehei & $0.088 \mathrm{mg} / \mathrm{mg} / \mathrm{h}$ & 38 \\
Aspergillus oryzae & $0.088 \mathrm{mg} / \mathrm{mg} / \mathrm{h}$ & 68 \\
ESL 001-01 & $0.33 \mathrm{mg} / \mathrm{mg} / \mathrm{h}$ & 87 \\
ChiroCLEC-CR & $0.33 \mathrm{mg} / \mathrm{mg} / \mathrm{h}$ & 99 \\
\hline
\end{tabular}

\subsection{Statistically designed experiments}

Subsequent reaction optimisation was performed through statistically designed experiments using Design-Ease (Stat-Ease Inc., USA). A $0.5 \times 2^{n-1} ; n=5$ factoral design (with duplicates and two midpoints) was applied. The results for the individual enzymes were as such:

(a) NOVO 388: The highest activity obtained was $38.8 \mathrm{~g} / \mathrm{l} / \mathrm{h}$ at $\mathrm{pH}=9$ in $20 \%$ PEG and with $10 \% \mathrm{w} / \mathrm{v}$ substrate, while the ee was $13 \%(S)$ (Table 3). The substrate concentration had no effect, but there were complex interactions between PEG, pH and DMSO. Conversly, the highest ee $(38 \%(S))$ was achieved under more acidic conditions at $\mathrm{pH} 5,20 \% \mathrm{PEG}$ and $2 \% \mathrm{w} / \mathrm{v}$ substrate, indicating that acidity was an important factor.

(b) NOVO 398: The highest activity was obtained using similar conditions to those for NOVO 388. Although the activity was lower $(16.9 \mathrm{~g} / \mathrm{l} / \mathrm{h})$ it gave a superior ee of $70.6 \%(S)$. Reducing the $\mathrm{pH}$ to 5 , and the substrate to $2 \%$ reduced the ee to only $57.6 \%(S)$. Although $\mathrm{pH}$ and PEG had some influence on activity, substrate concentration had a greater effect.

(c) Boehringer hog-liver esterase: As was the case with NOVO 388 and 398, the best activity was at $\mathrm{pH} 9$; 20\% PEG; $10 \%$ substrate and no DMSO. This result of $8.2 \mathrm{~g} / \mathrm{l} / \mathrm{h}$ was much higher than any of the other reaction medium combinations but gave an ee of only $24 \%(S)$. A higher ee $(33 \%(S))$ was obtained at pH 5; $20 \%$ PEG; $2 \%$ substrate and no DMSO, but the activity decreased to $2 \mathrm{~g} / \mathrm{l} / \mathrm{h}$. The substrate concentration did not seem to have any effect on the activity within the range investigated. PEG and DMSO had a negative influence on the higher activities possible at $\mathrm{pH} 9$.

(d) Aspergillus niger (Fluka): The PEG concentration had a large negative influence on the enzyme activity and the lowest PEG concentration was more favourable. A high substrate concentration (10\%) had negligible influence under alkaline conditions, but had a larger influence under acidic conditions. The highest activities $(0.32 \mathrm{~g} / \mathrm{g} / \mathrm{h})$ were obtained for $\mathrm{pH} 5$ and 9 with $10 \%$ substrate and a low PEG concentration (Table 3). At pH 9 only $7 \%(S)$ ee was achieved, while at $\mathrm{pH} 5$ the reaction gave an ee of $43.4 \%(S)$. DMSO had very little impact on the activity. 
Table 3

Summary of maximum hydrolysis of naproxen ethyl ester by means of a statistically designed experiment

\begin{tabular}{|c|c|c|c|c|c|c|c|c|}
\hline \multirow[t]{2}{*}{ Enzyme } & \multicolumn{4}{|c|}{ Optimum conditions } & \multirow[t]{2}{*}{ Major interactions } & \multirow[t]{2}{*}{ Primary influence } & \multirow[t]{2}{*}{ ee $(\%)$} & \multirow[t]{2}{*}{ Maximum activity } \\
\hline & $\mathrm{pH}$ & PEG $(\%, v / v)$ & $\operatorname{DMSO}(\%, \mathrm{v} / \mathrm{v})$ & Substrate $[\mathrm{s}](\%, \mathrm{~m} / \mathrm{v})$ & & & & \\
\hline NOVO 388 & 9 & 20 & 0 & 10 & PEG, pH, DMSO & $\mathrm{pH}$ & 13 & $38.8 \mathrm{~g} / \mathrm{l} / \mathrm{h}$ \\
\hline NOVO 398 & 9 & 20 & 0 & 10 & {$[\mathrm{~s}], \mathrm{pH}$} & {$[\mathrm{s}]$} & 70.6 & $16.9 \mathrm{~g} / \mathrm{l} / \mathrm{h}$ \\
\hline Hog-liver esterase & 9 & 20 & 0 & 10 & PEG, pH DMSO, pH & $\mathrm{pH}$ & 24 & $8.2 \mathrm{~g} / \mathrm{l} / \mathrm{h}$ \\
\hline Aspergillus niger & 5 & 20 & 20 & 10 & {$[\mathrm{~s}], \mathrm{pH}$} & PEG & 43.4 & $0.32 \mathrm{~g} / \mathrm{g} / \mathrm{h}$ \\
\hline Mucor miehei & 5 & 20 & 0 & 10 & PEG, [s] & {$[\mathrm{s}]$} & 27.8 & $0.36 \mathrm{~g} / \mathrm{g} / \mathrm{h}$ \\
\hline Aspergillus oryzae & 9 & 20 & 0 & 10 & {$[\mathrm{~s}], \mathrm{pH}$} & {$[\mathrm{s}]$} & 68 & $0.56 \mathrm{~g} / \mathrm{g} / \mathrm{h}$ \\
\hline ESL 001-01 & 9 & 20 & 0 & 10 & DMSO, $\mathrm{pH}$ & $\mathrm{pH}$ & 87 & $1.5 \mathrm{~g} / \mathrm{g} / \mathrm{h}$ \\
\hline
\end{tabular}

(e) Mucor miehei lipase: DMSO had a slightly negative effect. Although the $\mathrm{pH}$ did not influence activity $(0.36 \mathrm{~g} / \mathrm{g} / \mathrm{h})$, it did influence the enantioselectivity, with an ee of $10 \%(S)$ at $\mathrm{pH} 9$ and $27.8 \%(S)$ at $\mathrm{pH}$ 5. The highest activity was obtained at low PEG concentration and high substrate concentration (Table 3).

(f) Aspergillus oryzae lipase: the substrate concentration had a strongly positive effect on activity. The highest

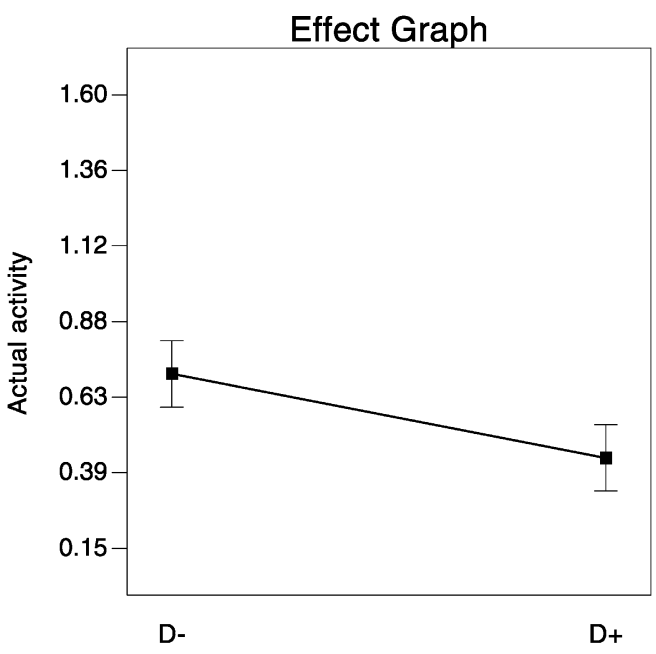

(a)

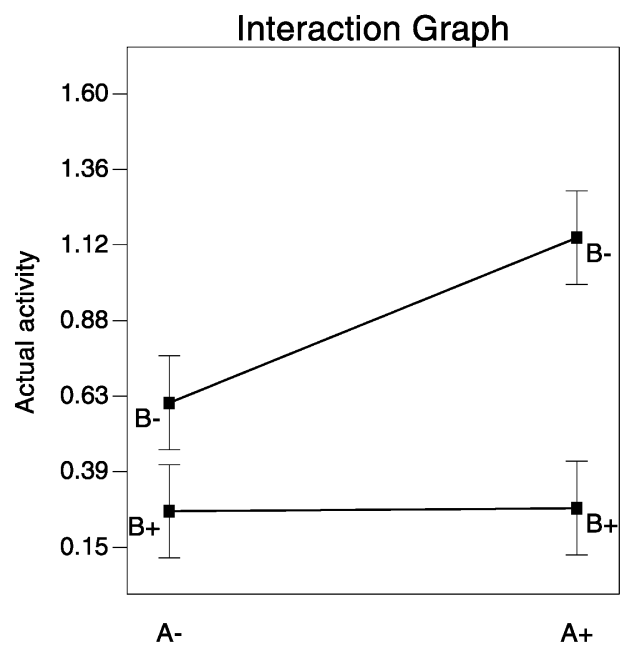

(b)

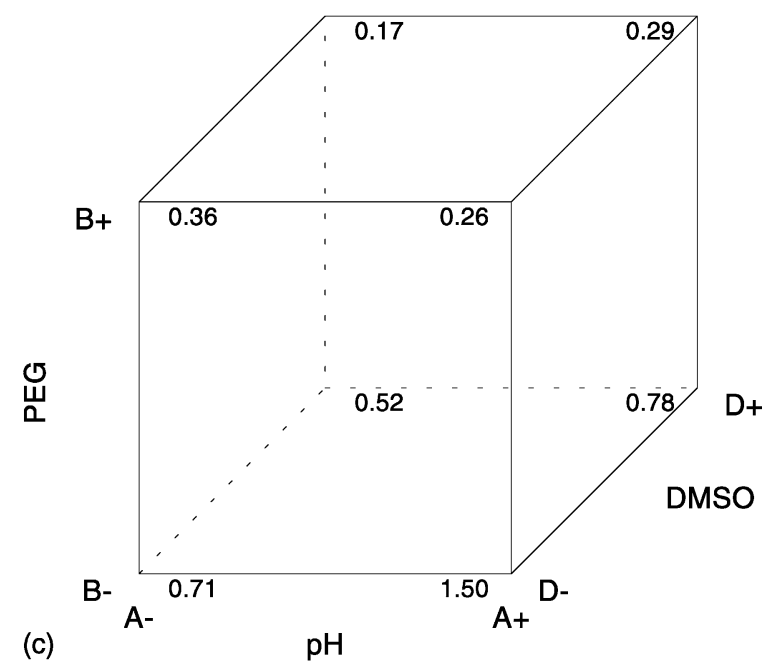

Fig. 1. Interactions that were significant for activity of ESL001-01. Addition of DMSO had a negative effect on activity (a) and from the interaction of $\mathrm{pH}$ and PEG it was clear that low PEG concentration and high $\mathrm{pH}$ gave the highest activity ( $\mathrm{b}$ and c). 
Table 4

Optimised enzyme enantioselectivity on $(S)$-naproxen ethyl ester

\begin{tabular}{|c|c|c|c|c|}
\hline \multirow[t]{2}{*}{ Enzyme } & \multicolumn{2}{|l|}{ Activity } & \multicolumn{2}{|c|}{ Enantioselectivity (ee) } \\
\hline & Measured & $\%$ of original activity* & eep $(\%)$ & Change in eep* \\
\hline NOVO 388 & $21.4 \mathrm{mg} / \mathrm{ml} / \mathrm{h}$ & 239 & 38 & -1 \\
\hline NOVO 398 & $16.9 \mathrm{mg} / \mathrm{ml} / \mathrm{h}$ & 626 & 70.6 & 4 \\
\hline Hog-liver esterase & $2 \mathrm{mg} / \mathrm{mg} / \mathrm{h}$ & 328 & 33 & 23 \\
\hline Aspergillus niger & $0.32 \mathrm{mg} / \mathrm{mg} / \mathrm{h}$ & 356 & 43.4 & 1 \\
\hline Mucor miehei & $0.36 \mathrm{mg} / \mathrm{mg} / \mathrm{h}$ & 409 & 27.8 & -10 \\
\hline Aspergillus oryzae & $0.56 \mathrm{mg} / \mathrm{mg} / \mathrm{h}$ & 636 & 68 & 0 \\
\hline ESL 001-01 & $1.5 \mathrm{mg} / \mathrm{mg} / \mathrm{h}$ & 455 & 87 & 0 \\
\hline ChiroCLEC-CR & $0.33 \mathrm{mg} / \mathrm{mg} / \mathrm{h}$ & 100 & 99 & 0 \\
\hline
\end{tabular}

* Compared to data in Table 2 .

Table 5

Biocatalytic conversion of $(S)$-naproxen ethyl ester

\begin{tabular}{lclr}
\hline Enzyme & \% conversion & eep $(\%)$ & $E$ \\
\hline NOVO 388 & 17.8 & 38 & 2.4 \\
NOVO 398 & 8.4 & 70.6 & 6.2 \\
Hog-liver esterase & 38 & 33 & 2.4 \\
Aspergillus niger & 4.4 & 43.4 & 2.6 \\
Mucor miehei & 3.0 & 27.8 & 1.8 \\
Aspergillus oryzae & 5.2 & 68 & 5.5 \\
ESL 001-01 & 13.5 & 87 & 16.3 \\
ChiroCLEC-CR & 40 & 99 & 397 \\
\hline
\end{tabular}

The conversions are in terms of $(R, S)$-naproxen and therefore a maximum of $50 \%$ is achievable.

activity was $0.56 \mathrm{~g} / \mathrm{g} / \mathrm{h}$ using a $\mathrm{pH}$ of $9,20 \%$ PEG, $10 \%$ substrate and no DMSO. The ee was $68 \%(S)$. The study revealed a detrimental influence of solvents such as DMSO and PEG on the rate of conversion by this lipase (Table 3).

(g) ESL001-01: According to the results of these experiments, the substrate concentration had no effect within the range investigated. The presence of DMSO diminished activity (Fig. 1), and it was clear that low PEG concentration at high $\mathrm{pH}$ gave the highest activity. The highest activity was obtained using pH 9, 20\% PEG, no DMSO and $10 \%$ substrate was $1.5 \mathrm{~g} / \mathrm{g} / \mathrm{h}$ (Table 3 ). The interaction between PEG, $\mathrm{pH}$ and DMSO is shown in Fig. 1c.

A summary of the improvements of the biocatalytic reactions with the selected enzymes through statistically designed experiments is shown in Table 4, where it is obvious that although dramatic improvements could be made in activity through modification of the reaction conditions, improvements to ee were far harder to achieve. The highest enantiomeric ratios $(E)$ achieved in this study are presented in Table 5.

\section{Discussion}

In this study, most of the available commercial lipases and esterases were screened for the enantioselective hydrolysis of racemic naproxen esters to yield $(S)$-naproxen. The only enzyme which gave excellent conversions of the racemic naproxen with an $E$ value of $>100$ and enantioselectivity of $>99 \%(S)$ was ChiroCLEC-CR (a crosslinked lipase from Candida cylindracea).

Seven other enzymes investigated in the present study gave acceptable activities, and hence the influence of reaction conditions was investigated using a statistically designed protocol in order to improve the enantiomeric ratio. From this selection only ESL001-01 gave an ee close to the desired minimum, but only a low conversion was achieved.

Generally the $\mathrm{pH}$ and substrate concentrations had the greatest influence on activity (as noted previously [5]). The addition of PEG (above 20\%) or DMSO as substrate dissolution agents was counterproductive in all cases.

Other groups have been investigating biocatalytic naproxen resolution. Xin et al [6] used a Candida rugosa lipase in comparative investigations of hydrolysis between an aqueous and an aqueous-organic biphasic system for enantiomeric resolution of $(S)-(+)$ naproxen. In the biphasic system a $42 \%$ conversion with $93 \%$ ee product was achieved providing an $E$ of approximately 50 in a trapped aqueous-organic solvent biphasic continuous reactor. Xin et al [7] also found that naproxen ester hydrolysis by a lipase in water-saturated organic solvent could be improved by linking it to a photo-hydrolytic reaction of methanol product to drive the reaction forward, but although the ee was good, only $25 \%$ conversion was achieved. Interestingly Chang et al [8] used a naproxen 2,2,2-trifluoroethyl thioester as substrate for lipase-mediated dynamic hydrolytic resolution in isooctane. Zhang et al [9] have recently demonstrated a Bacillus strain whole cell system capable of providing $(R)$-naproxen at $86 \%$ ee and $40-50 \%$ conversion from the ethyl ester racemate; while previous studies had discovered a Bacillus strain that preferentially generated the $S$-enantiomer [10].

The hydrolytic route has not been the only successful application of lipases in the resolution of naproxen racemates. Wu and Liu [11] achieved an excellent $E$ of 1200 by addition of small amounts of $n$-butanol to the organic solvent (isooctane) during lipase-mediated esterification of naproxen, but excess alcohol dramatically reduced the enantioselectivity of the reaction. Cui et al [12] achieved an ee of approximately $100 \%$ with $33.5 \%$ conversion (over 11 days) 
through lipase-catalysed esterification of racemic naproxen in organic solvent. Chang et al. $[13,14]$ used an enzymatic process for the preparation of $(S)$-naproxen ester in cyclohexane. Lipase MY and C. rugosa both gave an $E$ of $>100$, while addition of the small quantities of water in combination with surfactant bis(2-ethylhexyl)sodiumsulfosuccinate (AOT) to the cyclohexane dramatically improved the catalytic rate.

In the present study, it was observed that there was considerable variability in activity on NEE between commercial lipase preparations derived from the same species of organism (data not shown). The variability of enantioselectivity between lipase preparations generated from the same organism may often be due to the presence of variable quantities of contaminating enzymes with over-lapping activities (e.g. C. cylindracea lipase [15-17].

An alternative hydrolysis approach is to use not the ester of naproxen but its nitrile as a substrate for enzymatic enantiomeric resolution. This would involve a nitrilase or combination nitrile hydratase and amidase system. Layh et al [18] discovered bacteria that could hydrolyse the naproxen nitrile, providing $99 \%(S)$-naproxen with $40 \%$ conversion of the racemic substrate.

These studies demonstrate the versatility of enzymes in organic synthesis, allowing exploration of various synthetic routes and reaction media. The increasing selection of commercially available enzymes will enable rapid expansion of commercial syntheses involving biocatalysis. In the present study it was shown that the use of both novel and known, purified enzymes can provide suitable activities for enantiomeric resolution of a commercial chiral product.

\section{Acknowledgments}

The authors wish to thank AECI for permission to publish this work. We appreciate Mr. G. Davies and N. Wilde for analytical support, and Mrs. I. Auret for statistical processing of the data. We would like to thank Enzymes SA (Pty) for kind donation of enzyme samples and Mr. J. Khaile for preparation of the substrate.

\section{References}

[1] Patel RN. Stereoselective biocatalysis. New York: Marcel Dekker Inc., 2000. ISBN 0-8247-8282-8.
[2] Tsai SW, Wei H-J. Enantioselective esterification of racemic naproxen by lipases in organic solvent. Enz Microb Technol 1994;16: 328-33.

[3] Sonawane RH, Bellur NS, Ahuja JR. Recent developments in the synthesis of optically active 2-arylpropionic acids: an important class of nonsteroidal anti-inflammatory agents. Tetrahedron: Asymmetry 1992;3:163-92.

[4] Sheldon RA. Chirotechnology: industrial synthesis of optically active compounds. New York: Marcel Dekker, Inc., 1993. ISBN 0-8247-9143-6. p. 82-4.

[5] Moreno JM, Samoza A, del Campo C, Llama E, Sinisterra JV. Hydrolysis of 2-aryl propionic and 2-ary butyric esters with immobilized Candida cylindracea lipase. J Mol Cat A: Chem 1995;95:179-92.

[6] Xin J-Y, Li S-B, Xi Y, Wang L-L. Enantiomeric resolution of (S)-(+) naproxen in a trapped aqueous-organic solvent biphase continuous reactor. Biotech Bioeng 2000;68:78-83.

[7] Xin J-Y, Li S-B, Chen X-H, Wang L-L, Xu Y. Improvement of the enantioselectivity of lipase-catalyzed naproxen ester hydrolysis in organic solvent. Enz Microb Technol 2000;26:137-41.

[8] Chang C-S, Tsai, S-W, Kuo J. Lipase-catalyzed dynamic resolution of naproxen 2,2,2-trifluoroethyl thioester by hydrolysis in isooctane. Biotechnol Bioeng 1999;64:120-6.

[9] Zhang J, Hou Z, Yao C, Yu J. Purification and properties of lipase from a Bacillus strain for catalytic resolution of $(R)$-naproxen. $\mathrm{J}$ Mol Cat B Enz 2002;18:205-10.

[10] Smeets JWH, Kieboom APG. Enzymatic enantioselectivie ester hydrolysis by carboxyesterase NP. Recl Trav Chim Pays-Bas 1992;111:490-5.

[11] Wu JY, Liu S-W. Influence of alcohol concentration on lipase-catalyzed enantioselective esterification of racemic naproxen in isooctane: under controlled water activity. Enz Microb Technol 2000;26:124-30.

[12] Cui Y-M, Wei D-Z, Yi J-T. Lipase-catalysed esterification in organic solvent to resolve racemic naproxen. Biotechnol Lett 1997;19: $865-8$.

[13] Chang C-S, Tsai S-W. Surfactant effect on enhancing (S)-naproxen prodrug production from racemic naproxen by lipase. Appl Biochem Biotechnol 1997;68:135-42.

[14] Chang C-S, Tsai S-W, Fernández VM, Otero C, Ballesteros A. A facile enzymatic process for the preparation of $(S)$-naproxen ester prodrug in organic solvents. Enz Microb Technol 1997;20:635-9.

[15] Rúa ML, Díaz-Mauriño T, Fernández VM, Otero C, Ballesteros A. Purification and characterisation of two distinct lipases from (Candida cylindracea). Biochim Biophys Acta 1993;1156:181-9.

[16] Kim MG, Lee EG, Chung BH. Improved enantioselectivity of Candida rugosa lipase towards ketoprofen ethyl ester by a simple two-step treatment. Proc Biochem 2000;35:977-82.

[17] Hernáiz MJ, Sánchez-Montero JM, Sinisterra JV. Hydrolysis of (R, S) 2-aryl propionic esters by pure lipase B from Candida cylindracea. J Mol Cat A: Chem 1995;96:317-27.

[18] Layh N, Hirrilinger B, Stolz A, Knackmuss H-J. Enrichment strategies for nitrile-hydrolysing bacteria. Appl Microbiol Biotechnol 1997;47:668-74. 